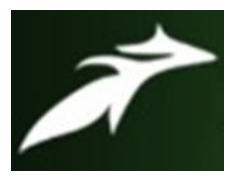

Said Asif Sarbaz et al, International Journal of Advances in Agricultural Science \& Technology,

Vol.8 Issue.12, December-2021, pg. 1-10

ISSN: 2348-1358

Impact Factor: 6.057

NAAS Rating: 3.77

\title{
Impact of Nitrogen Nutrition through Organic and Inorganic Sources of Fertilizer on Growth Phenology and Yield of Wheat (Triticum aestivum L.)
}

\author{
Said Asif Sarbaz ${ }^{1}$; Satish Kumar²; Suresh Kumar³ Kautilya Chaudhary ${ }^{4}$; \\ Jogander Kumar ${ }^{5}$; Vinod Kumar Malik \\ ${ }^{1}$ Research Farm Manager, Department of Agriculture, Irrigation and Livestock Nangarhar-2601 (DAIL-N), Ministry of \\ Agriculture, Afghanistan \\ E-mail: asif.sayeed1789@gmail.com \\ ${ }^{2}$ Senior Scientist, Department of Agronomy, Agricultural University, Hisar Haryana 125004, India \\ E-mail: skkhokhar64@gmail.com \\ ${ }^{3}$ Assistant Director (Crop), Directorate of Research, Agricultural University, Hisar, Haryana 125004, India \\ E-mail: sureshsilla@hau.ac.in \\ ${ }^{4}$ Assistant Scientist, Department of Agronomy (Soil Science), Agricultural University, Hisar, Haryana 125004, India \\ E-mail: kautilya@hau.ac.in \\ ${ }^{5}$ Assistant Scientist, Department of Agricultural Economics, Agricultural University, Hisar, Haryana 125004, India \\ E-mail: joginder.stats@hau.ac.in \\ ${ }^{6}$ Assistant Professor, Department of Plant Pathology, Agricultural University, Hisar Haryana 125004, India \\ E-mail: vmexcel@ rediffmail.com \\ DOI: 10.47856/ijaast.2021.v08i12.001
}

\begin{abstract}
The field experiment was conducted at wheat research farm of CCS Haryana Agriculture University during Rabi season of 2019-20 to study nitrogen nutrition through organic and inorganic source of fertilizer on growth phenology, yield and quality of wheat (Triticum aestivum L.) The experiment was laid out in randomized block design with three replications containing 16 treatments combination i.e $\mathrm{T}_{1}$-Control; $\mathrm{T}_{2}-100 \% \mathrm{RDN}$ through urea; $\mathrm{T}_{3^{-}}$ $100 \%$ RDN through FYM; $\mathrm{T}_{4}-100 \%$ RDN through vermicompost; $\mathrm{T}_{5}-50 \%$ RDN through urea $50 \%$ RDN through FYM; $\mathrm{T}_{6}-50 \%$ RDN through urea+ 50\% RDN through vermicompost; $\mathrm{T}_{7}-25 \% \mathrm{RDN}$ through urea+ $75 \%$ RDN through FYM; $\mathrm{T}_{8}-25 \%$ RDN through urea $75 \% \mathrm{RDN}$ through vermicompost; $\mathrm{T}_{9}-100 \% \mathrm{RDN}$ through urea + Azotobacter; $\mathrm{T}_{10}-100 \%$ RDN through FYM + Azotobacter; $\mathrm{T}_{11}-100 \%$ RDN through vermicompost + Azotobacter; $\mathrm{T}_{12}-50 \%$ RDN through urea+ 50\% RDN through FYM + Azotobacter $; \mathrm{T}_{13}-50 \%$ RDN through urea+ 50\% RDN through vermicompost + Azotobacter $; \mathrm{T}_{14}-25 \%$ RDN through urea+ $75 \%$ RDN through FYM + Azotobacter; $\mathrm{T}_{15^{-}}$ $25 \% \mathrm{RDN}$ through urea+ $75 \% \mathrm{RDN}$ through vermicompost + Azotobacter; $\mathrm{T}_{16}$ - Azotobacter. Treatment $\mathrm{T}_{9}, 100 \%$ nitrogen nutrition through chemical fertilizer (urea) with seed treatment of Azotobacter has taken significantly maximum days to emergence (5.3). Days taken to 50\% spike emergence (94.7) and days taken to maturity (148.0) respectively. Similarly $T_{9}$ had significantly higher grain yield $(5640 \mathrm{~kg} / \mathrm{ha})$, hectoliter weight $(83.167 \mathrm{~kg} / \mathrm{ha})$, grain appearance score (7.933 scale/10) and protein content (12.90\%) of wheat during the research period respectively. Keywords: organic and inorganic nitrogen nutrition, growth phenology, Azotobacter.
\end{abstract}




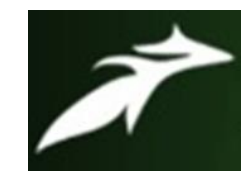

Said Asif Sarbaz et al, International Journal of Advances in Agricultural Science \& Technology, Vol.8 Issue.12, December-2021, pg. 1-10

ISSN: 2348-1358

Impact Factor: 6.057

NAAS Rating: 3.77

\section{Introduction}

Wheat (Triticum aestivum L.) is one of the world's leading cereal crop, which can be grown in wide range of altitudes and latitudes. Wheat is one of the good sources of carbohydrates and unique protein, which is consumed as human food as well as animal feed. It is the staple food of nearly $35 \%$ of world population. Globally wheat was grown in around 215.45 million hectares during 2018-19, holding the highest position in acreage among all other crops with yearly production of 370.84 million tonnes with the yield of $3390 \mathrm{~kg} / \mathrm{ha}$ (USDA, 2020). Wheat cultivation has also been sign of green revolution, self-sufficiency in food and sustained production (Alam et al., 2013). India is the second largest producer of wheat next to China, which produces about 107.59 million tons of wheat from an area of 29.6 million hectare with an average productivity of $3508 \mathrm{~kg} \mathrm{ha}^{-1}$. The states which produce significant amount of wheat are Haryana, Uttar Pradesh, Punjab, Rajasthan, Gujarat, Madhya Pradesh, Bihar and Maharashtra. Haryana produces 12.57 million tons of wheat from 2.55 million hectare in year 2018-19, with an average productivity of $4925 \mathrm{~kg} \mathrm{ha}^{-1}$ (Anonymous, 2020). Because of complex genome nature of wheat it has wider adaptability, therefore, it is grown from temperate irrigated to dry and high rainfall areas and from warm humid to dry cold environmental conditions and being a $\mathrm{C}_{3}$ type crop, it thrives well in cool environment (Anonymous, 2015). Wheat is cultivated principally in two seasons in the world viz., winter and spring. Winter wheat is cultivated in temperate zones viz., Europe, USA and Russian Federation etc. which withstand frozen status during early stages of its life cycle, while spring wheat is grown in Asia and parts of USA, which do not undergo freezing temperature. Winter wheat matures in 240-300, days while spring wheat matures in 100-150 days depending upon temperature. Wheat can be grown from below sea level depth up to 5000 meter altitude and in areas where the precipitation prevails between 300-1130 mm annually (Bhardwaj et al., 2010). Due to intensive cropping, where food grain production and fertilizer application run parallel, soil is degrading day by day with respect to soil fertility and productivity. Meanwhile, agriculture becomes more intensive and chemical dependent, therefore soil toxicities and nutrient imbalance threaten sustainable production. Therefore, we have to consider about the low-cost and easily available alternative source of nitrogen, which not only supply the nitrogen to the soil but also develop the physico-chemical properties of the soil. Thus, demand for fertilizers can be lowered by supplementing the nutrients through organic manures and biofertilizers. To overcome the problem 


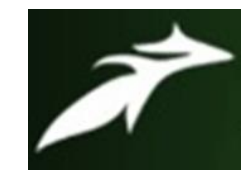

Said Asif Sarbaz et al, International Journal of Advances in Agricultural Science \& Technology, Vol.8 Issue.12, December-2021, pg. 1-10

ISSN: 2348-1358

Impact Factor: 6.057

NAAS Rating: 3.77

of nutrient deficiency and to increase wheat yield, the farmers are using chemical fertilizers. However, the chemical fertilizers are costly and the small farmers cannot afford to use these fertilizers in appropriate amount and balanced proportion. Under such condition integrated use of chemical and organic fertilizer can play an important role to maintain soil fertility and crop productivity. Nitrogen is one of the most important nutrients applied to crop for higher yield and quality, but its balanced use is a key point for healthy environment and higher land effectiveness, which can be attain through integrated nitrogen management (Iqbal et al., 2012). Biofertilizers are a good approach to increase crop productivity. Nowadays, the biofertilizers are used to supply the important nutrients to the plant and significantly increase its productivity. These are eco-friendly, cost effective, provides the natural environment to the plant, boost the protection system of the plant, and protect the plant from drought, acidity, and other unfavorable conditions (Nosheen et al., 2020).

\section{Materials and Methods}

The field experiment was conducted at wheat research farm of CCS Haryana Agriculture University during Rabi season of 2019-20 to study the economics of wheat under integrated nitrogen management. The experiment was laid out in randomized block design with three replications containing 16 treatments combination i.e. $\mathrm{T}_{1}$-Control; $\mathrm{T}_{2}-100 \% \mathrm{RDN}$ through urea; $\mathrm{T}_{3}-100 \% \mathrm{RDN}$ through FYM; $\mathrm{T}_{4}-100 \%$ RDN through vermicompost; $\mathrm{T}_{5}-50 \%$ RDN through urea+ $50 \%$ RDN through FYM; $\mathrm{T}_{6}-50 \%$ RDN through urea+ 50\% RDN through vermicompost; $\mathrm{T}_{7}-25 \% \mathrm{RDN}$ through urea+ 75\% RDN through FYM; $\mathrm{T}_{8}-25 \%$ RDN through urea $75 \%$ RDN through vermicompost; $\mathrm{T}_{9^{-}}$ $100 \%$ RDN through urea + Azotobacter $; \mathrm{T}_{10}-100 \%$ RDN through FYM + Azotobacter $; \mathrm{T}_{11}-100 \%$ RDN through vermicompost + Azotobacter; $\mathrm{T}_{12}-50 \% \mathrm{RDN}$ through urea+ 50\% RDN through FYM + Azotobacter; $\mathrm{T}_{13}-50 \% \mathrm{RDN}$ through urea+ $50 \% \mathrm{RDN}$ through vermicompost + Azotobacter $; \mathrm{T}_{14}-25 \%$ RDN through urea+ 75\% RDN through FYM + Azotobacter; $\mathrm{T}_{15}-25 \%$ RDN through urea+ 75\% RDN through vermicompost + Azotobacter; $\mathrm{T}_{16^{-}}$Azotobacter. The initial status of soil fertility was 130:17:250 kg NPK ha ${ }^{-1}$ with 0.37 percent organic carbon. The wheat variety WH 1184 used for sowing at the rate of $120 \mathrm{~kg} / \mathrm{ha}$. Both the FYM and vermicompost were analyzed for available nitrogen and were made to percent RDN. The FYM and vermicompost were broadcasted as per treatments. Half dose of nitrogen through urea was applied before sowing as per treatments, along 


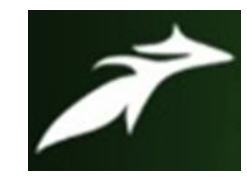

Said Asif Sarbaz et al, International Journal of Advances in Agricultural Science \& Technology, Vol.8 Issue.12, December-2021, pg. 1-10

ISSN: 2348-1358

Impact Factor: 6.057

NAAS Rating: 3.77

with full dose of $\mathrm{P}, \mathrm{K}$ and $\mathrm{Zn}$, and second half dose after first irrigation. All the agronomic operation were equally done for all the treatments. The only differences among the treatments were the rate and source of nitrogen nutrition. The phonological days were counted from days of sowing and the protein content of wheat was calculated by multiplying the nitrogen content of wheat by 6.25 .

\section{Results and Discussion}

\subsection{Growth phenology}

Growth is an irreversible process by which a plant increases in size or dry weight or volume. Plants receive energy for their growth from sunlight through photosynthesis process. However, utilization of manufactured energy by crop depends upon the development stage and environmental conditions and also photosynthate formation rate in somewhat temperature related. The data presented in Table 1 indicated that days taken to emergence of wheat was not influenced significantly by any of the treatments. Days taken to 50\% Spike emergence days was significantly lower in control treatment as compared to rest of treatment. The maximum days taken to $50 \%$ spike emergence was recorded in $100 \%$ RDN through urea + Azotobacter (94.7 days) which was statistically at par with 100\% RDN through urea alone. Nutrition of nitrogen through organic source i.e. FYM or vermicompost resulted in significantly earlier emergence of spikes as compared to nitrogen nutrition through chemical fertilizer i.e urea. Decrease in contribution of nitrogen through urea in combination with organic source nitrogen nutrition decreased number of days to spike emergence significantly with decrease in $\mathrm{N}$ nutrition through chemical fertilizer (urea). Seed treatment with Azotobacter irrespective of the integrated nitrogen management failed to produce significant variation in days taken to $50 \%$ spike emergence. Seed treatment with Azotobacter delayed 50\% spike emergence significantly as compared to control treatment but it was significantly lower than integrated use of RDN through urea with FYM or vermicompost at either of the integrated nitrogen management treatment. Nitrogen nutrition either through urea or FYM or vermicompost resulted in increase in days taken to maturity of wheat crop significantly over control treatment. Nitrogen nutrition through any of the organic source i.e FYM or vermicompost resulted in significantly earlier maturity of wheat as compared to nitrogen nutrition through chemical fertilizers (urea). Integration of organic source of nitrogen nutrition i.e 50:50 or 25:75 with chemical fertilizer resulted in significantly earlier maturity of wheat as compared to alone 


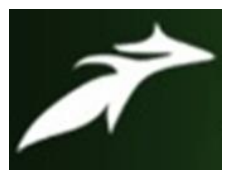

Said Asif Sarbaz et al, International Journal of Advances in Agricultural Science \& Technology, Vol.8 Issue.12, December-2021, pg. 1-10

ISSN: 2348-1358 Impact Factor: 6.057

NAAS Rating: 3.77

$100 \%$ RDN nutrition through urea. Seed treatment of wheat with Azotobacter in either of the integrated nutrient treatments failed to produce significant variation in maturity of wheat as compared to no Azotobacter seed treatment in the respective integrated nitrogen management treatment. Nitrogen nutrition $100 \%$ through vermicompost + Azotobacter delayed the wheat maturity as compared to $100 \%$ RDN through vermicompost alone. Sarwar et al. (2007) also reported that nitrogen availability was 40 only percent for manure. No much difference in maturity was recorded if nitrogen supply was $50 \%$ through urea $+50 \% \mathrm{FYM} /$ vermicompost as compared to the same treatment combination with Azotobacter seed treatment which might be due to no significant supply of nitrogen by Azotobacter. However, it improved the nutrient (nitrogen) availability.

Table 1. Effect of integrated nitrogen management on phenology of wheat (Triticum aestivum L.)

\begin{tabular}{|l|c|c|c|}
\hline \multirow{2}{*}{ Treatments } & \multicolumn{3}{|c|}{ Days taken to } \\
\cline { 2 - 4 } & Emergence & $\begin{array}{c}\text { 50\% spike } \\
\text { emergence }\end{array}$ & Maturity \\
\hline $\mathrm{T}_{1}:$ Control & 5.1 & 77.7 & 132.0 \\
\hline $\mathrm{T}_{2}: 100 \% \mathrm{RDN}$ through urea & 5.0 & 94.3 & 148.3 \\
\hline $\mathrm{T}_{3}: 100 \% \mathrm{RDN}$ through FYM & 5.1 & 87.0 & 141.3 \\
\hline $\mathrm{T}_{4}: 100 \% \mathrm{RDN}$ through vermicompost & 5.2 & 90.3 & 143.3 \\
\hline $\mathrm{T}_{5}: 50 \% \mathrm{RDN}$ through urea+ 50\% RDN through FYM & 5.0 & 91.7 & 144.3 \\
\hline $\begin{array}{l}\mathrm{T}_{6}: 50 \% \mathrm{RDN} \text { through urea+ 50\% RDN through } \\
\text { vermicompost }\end{array}$ & 5.1 & 92.3 & 145.7 \\
\hline $\mathrm{T}_{7}: 25 \% \mathrm{RDN}$ through urea+ 75\% RDN through FYM & 5.1 & 88.0 & 143.0 \\
\hline $\begin{array}{l}\mathrm{T}_{8}: 25 \% \mathrm{RDN} \text { through urea+ 75\% RDN through } \\
\text { vermicompost }\end{array}$ & 5.2 & 87.3 & 144.0 \\
\hline $\mathrm{T}_{9}: 100 \% \mathrm{RDN}$ through urea + Azotobacter & 5.3 & 94.7 & 148.0 \\
\hline $\mathrm{T}_{10}: 100 \% \mathrm{RDN}$ through FYM + Azotobacter & 5.2 & 87.3 & 142.0 \\
\hline $\mathrm{T}_{11}: 100 \% \mathrm{RDN}$ through vermicompost + Azotobacter & 5.1 & 91.7 & 144.0 \\
\hline $\begin{array}{l}\mathrm{T}_{12}: 50 \% \mathrm{RDN} \text { through urea+ 50\% RDN through FYM } \\
\text { Azotobacter }\end{array}$ & 5.2 & 92.0 & 145.0 \\
\hline
\end{tabular}




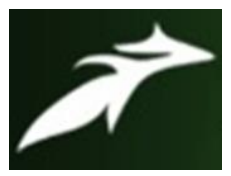

Said Asif Sarbaz et al, International Journal of Advances in Agricultural Science \& Technology, Vol.8 Issue.12, December-2021, pg. 1-10

ISSN: 2348-1358

Impact Factor: 6.057

NAAS Rating: 3.77

\begin{tabular}{|c|c|c|c|}
\hline $\begin{array}{l}\mathrm{T}_{13}: 50 \% \mathrm{RDN} \text { through urea+ } 50 \% \mathrm{RDN} \text { through } \\
\text { vermicompost }+ \text { Azotobacter }\end{array}$ & 5.0 & 93.0 & 146.0 \\
\hline $\begin{array}{l}\mathrm{T}_{14}: 25 \% \mathrm{RDN} \text { through urea+ } 75 \% \mathrm{RDN} \text { through FYM + } \\
\text { Azotobacter }\end{array}$ & 5.1 & 88.7 & 143.3 \\
\hline $\begin{array}{l}\mathrm{T}_{15}: 25 \% \mathrm{RDN} \text { through urea }+75 \% \mathrm{RDN} \text { through } \\
\text { vermicompost }+ \text { Azotobacter }\end{array}$ & 5.1 & 89.0 & 143.7 \\
\hline $\mathrm{T}_{16}:$ Azotobacter & 5.1 & 88.0 & 136.0 \\
\hline $\mathrm{SE}(\mathrm{m}) \pm$ & 0.9 & 1.0 & 1.0 \\
\hline $\mathrm{CD}$ at $5 \%$ & NS & 2.1 & 2.4 \\
\hline
\end{tabular}

\subsection{Yield studies}

Among different treatments highest grain yield was recorded in 100\% RDN through urea + Azotobacter which was 22, 22.8, 29.9 and 25.1 percent higher than $\mathrm{T}_{5}(50 \% \mathrm{RDN}$ through urea $+50 \%$ RDN through FYM), $\mathrm{T}_{6}\left(50 \% \mathrm{RDN}\right.$ through urea $+50 \% \mathrm{RDN}$ through vermicompost), $\mathrm{T}_{7}$ (25\% RDN through urea $+75 \%$ RDN through FYM), and $\mathrm{T}_{8}(25 \%$ RDN through urea $+75 \%$ RDN through vermicompost). No significant variation in grain yield of wheat was recorded at the same proportion i.e 50:50 or 25:75 ratio of chemical fertilizer and organic fertilizer if organic source was FYM or vermicompost, however, higher proportion of urea i.e. 50\% RDN produced significantly higher grain yield as compared to $25 \%$ proportion. Treatment having $50 \%$ RDN through urea $+50 \%$ RDN through vermicompost produced 3 percent higher grain yield as compared to 25\% RDN through urea $+75 \%$ RDN through vermicompot. Nutrition of $100 \%$ RDN in wheat through chemical fertilizer recorded 28.58 and 27.79 percent higher grain yield as compared to FYM and vermicompost, respectively. Seed treatment of wheat with Azotobacter along with 50\% RDN through urea + 50\% RDN through FYM or vermicompost improved the grain yield by 458 and $288 \mathrm{~kg} / \mathrm{ha}$, respectively over no inoculation. Similarly, Azotobacter seed treatment had positive impact on wheat grain yield at different combination of chemical fertilizer and organic sources (FYM or vermicompost). Nitrogen nutrition $100 \%$ through urea produced 23.74 percent higher grain yield as compared to $\mathrm{T}_{15}(25 \%$ RDN through urea $+75 \%$ RDN through vermicompost + Azotobacter). 


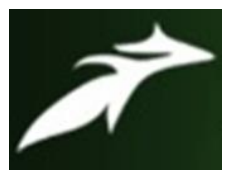

Said Asif Sarbaz et al, International Journal of Advances in Agricultural Science \& Technology, Vol.8 Issue.12, December-2021, pg. 1-10

ISSN: 2348-1358

Impact Factor: 6.057

NAAS Rating: 3.77

Table 2: impact of nitrogen nutrition on yield and quality of wheat

\begin{tabular}{|c|c|c|c|c|c|}
\hline Treatments & $\begin{array}{l}\text { Grain } \\
\text { yield } \\
\text { (kg/ha) }\end{array}$ & $\begin{array}{c}\text { Hectoliter } \\
\text { weight } \\
\text { (kg/ha) }\end{array}$ & $\begin{array}{c}\text { Grain } \\
\text { appearance } \\
\text { score } \\
\text { (10 scale) }\end{array}$ & $\begin{array}{c}\text { Protein } \\
\text { content } \\
(\%)\end{array}$ & $\begin{array}{c}\text { Protein } \\
\text { Yield } \\
\text { (kg/ha) }\end{array}$ \\
\hline $\mathrm{T}_{1}$ : Control & 3911 & 77.207 & 6.167 & 7.48 & 383.05 \\
\hline $\mathrm{T}_{2}: 100 \% \mathrm{RDN}$ through urea & 5600 & 83.167 & 7.700 & 12.89 & 721.84 \\
\hline $\mathrm{T}_{3}: 100 \%$ RDN through FYM & 4000 & 79.933 & 6.667 & 12.00 & 480.00 \\
\hline $\mathrm{T}_{4}: 100 \% \mathrm{RDN}$ through vermicompost & 4044 & 80.300 & 6.700 & 12.08 & 488.62 \\
\hline $\begin{array}{l}\mathrm{T}_{5}: 50 \% \mathrm{RDN} \text { through urea+ } 50 \% \mathrm{RDN} \\
\text { through FYM }\end{array}$ & 4400 & 82.133 & 6.967 & 11.73 & 516.18 \\
\hline $\begin{array}{l}\mathrm{T}_{6}: 50 \% \mathrm{RDN} \text { through urea+ } 50 \% \mathrm{RDN} \\
\text { through vermicompost }\end{array}$ & 4355 & 82.267 & 7.333 & 11.79 & 513.69 \\
\hline $\begin{array}{l}\mathrm{T}_{7}: 25 \% \mathrm{RDN} \text { through urea+ } 75 \% \mathrm{RDN} \\
\text { through FYM }\end{array}$ & 4177 & 81.167 & 6.933 & 9.79 & 312.55 \\
\hline $\begin{array}{l}\mathrm{T}_{8}: 25 \% \mathrm{RDN} \text { through urea+ } 75 \% \mathrm{RDN} \\
\text { through vermicompost }\end{array}$ & 4222 & 81.167 & 7.067 & 11.64 & 491.63 \\
\hline $\mathrm{T}_{9}: 100 \% \mathrm{RDN}$ through urea + Azotobacter & 5640 & 83.167 & 7.933 & 12.90 & 727.56 \\
\hline $\mathrm{T}_{10}: 100 \% \mathrm{RDN}$ through FYM +Azotobacter & 4133 & 80.900 & 6.700 & 11.23 & 464.18 \\
\hline $\begin{array}{l}\mathrm{T}_{11}: 100 \% \mathrm{RDN} \text { through vermicompost } \\
+ \text { Azotobacter }\end{array}$ & 4266 & 80.067 & 6.767 & 11.11 & 474.03 \\
\hline $\begin{array}{l}\mathrm{T}_{12}: 50 \% \mathrm{RDN} \text { through urea+ } 50 \% \mathrm{RDN} \\
\text { through FYM }+ \text { Azotobacter }\end{array}$ & 4502 & 83.067 & 7.500 & 11.77 & 529.86 \\
\hline $\begin{array}{l}\mathrm{T}_{13}: 50 \% \mathrm{RDN} \text { through urea+ } 50 \% \mathrm{RDN} \\
\text { through vermicompost }+ \text { Azotobacter }\end{array}$ & 4688 & 83.100 & 7.533 & 11.88 & 556.81 \\
\hline $\begin{array}{l}\mathrm{T}_{14}: 25 \% \mathrm{RDN} \text { through urea+ } 75 \% \mathrm{RDN} \\
\text { through FYM }+ \text { Azotobacter }\end{array}$ & 4211 & 80.067 & 7.000 & 11.71 & 492.97 \\
\hline $\begin{array}{l}\mathrm{T}_{15}: 25 \% \mathrm{RDN} \text { through urea+75\% RDN } \\
\text { through vermicompost+Azotobacter }\end{array}$ & 4271 & 81.700 & 7.100 & 11.69 & 499.19 \\
\hline $\mathrm{T}_{16}:$ Azotobacter & 4044 & 79.200 & 6.300 & 10.46 & 422.90 \\
\hline $\mathrm{SEm} \pm$ & 136 & 0.480 & 0.334 & 0.647 & 8.333 \\
\hline $\mathrm{CD}$ at $5 \%$ & 296 & 1.392 & 0.970 & 1.87 & 24.18 \\
\hline
\end{tabular}




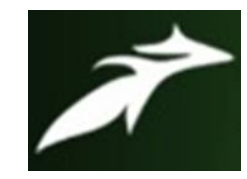

Said Asif Sarbaz et al, International Journal of Advances in Agricultural Science \& Technology, Vol.8 Issue.12, December-2021, pg. 1-10

ISSN: 2348-1358

Impact Factor: 6.057

NAAS Rating: 3.77

\section{Conclusion}

Among different treatments highest grain yield was recorded in 100\% RDN through urea + Azotobacter than $\mathrm{T}_{5}\left(50 \%\right.$ RDN through urea $+50 \%$ RDN through FYM), $\mathrm{T}_{6}(50 \%$ RDN through urea + $50 \%$ RDN through vermicompost), $\mathrm{T}_{7}\left(25 \% \mathrm{RDN}\right.$ through urea $+75 \% \mathrm{RDN}$ through FYM), and $\mathrm{T}_{8}(25 \%$ RDN through urea $+75 \%$ RDN through vermicompost). No significant variation in grain yield of wheat was recorded at the same proportion i.e 50:50 or 25:75 ratio of chemical fertilizer and organic fertilizer if organic source was FYM or vermicompost, however, higher proportion of urea i.e $50 \%$ urea produced significantly higher grain yield as compared to $25 \%$ proportion. Treatment having $50 \%$ RDN through urea $+50 \%$ RDN through vermicompost produce 3 percent higher grain yield as compared to $25 \% \mathrm{RDN}$ through urea $+75 \%$ RDN through vermicompost. Seed treatment of wheat with Azotobacter along with $50 \%$ RDN through urea $+50 \%$ RDN through FYM or vermicompost improved the grain by 458 and 288 $\mathrm{kg} / \mathrm{ha}$, respectively or no inoculation.

Days taken to emergence of wheat was not influenced significantly by any treatments.

Days taken to 50\% spike emergence was significantly higher in control treatment as compared to rest of treatment. The maximum days taken to $50 \%$ spike emergence was recorded in $100 \%$ RDN through urea + Azotobacter (94.4 days) which was statistically at par with $100 \%$ urea alone. Nutrition of nitrogen through organic source i.e. FYM or vermicompost resulted in significantly earlier emergence of spikes as compared to nitrogen nutrition through chemical fertilizer i.e. urea.

Nitrogen nutrition through FYM or vermicompost resulted in significantly earlier maturity of wheat as compared to nitrogen nutrition through chemical fertilizers (urea) integration of organic source of nitrogen nutrition i.e 50:50 or 25:75 with chemical fertilizer resulted in significantly earlier maturity of wheat as compared to alone $100 \% \mathrm{~N}$ nutrition through urea. Seed treatment of wheat with Azotobacter in either of the integrated nutrient treatments failed to produce significant variation in maturity of wheat as compared to no Azotobacter seed treatment in the respective integrated nitrogen treatment. $100 \%$ nitrogen nutrition through vermicompost + Azotobacter delayed the wheat maturity as compared to $100 \%$ RDN through vermicompost alone. 


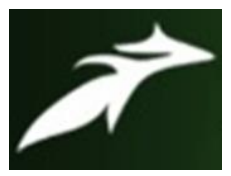

Said Asif Sarbaz et al, International Journal of Advances in Agricultural Science \& Technology, Vol.8 Issue.12, December-2021, pg. 1-10

ISSN: 2348-1358

Impact Factor: 6.057

NAAS Rating: 3.77

\section{References}

[1]. Alam, M. P., Kumar, S., Ali, N., Manjhi, R. P., Kumari, N., Lakra, R. K., \& Izhar, T. (2013). Performance of wheat varieties under different sowing dates in Jharkhand. Journal of Wheat Research, 5(2): 61-64.

[2]. Anonymous, (2020). Economic survey of Haryana 2019-20.

[3]. Anonymous (2015). Deptt. Of Economics and Statistics. Govt. of India.

[4]. Bhardwaj, V., Yadav, V., \& Chauhan, B. S. (2010). Effect of nitrogen application timings and varieties on growth and yield of wheat grown on raised beds. Archives of Agronomy and Soil Science, 56(2): 211-222.

[5]. Iqbal, J., Hayat, K., Hussain, S., Ali, A., and Bakhsh, M. A. A. H. A. (2012). Effect of seeding rates and nitrogen levels on yield and yield components of wheat (Triticum aestivum L.). Pakistan Journal of Nutrition, 11(7): 53.

[6]. Nosheen, S, Ajmal, L song, Y. Microbes as Biofertilizers, a potential Approach for sustainable crop production. Sustainability 2020, 13, 1868.

[7]. Sarwar G, Hussain N, Schmeisky H. and Muhammad, S. (2007), Use of compost an environment friendly technology for enhancing rice-wheat production in Pakistan. Pak J Bot 39 (5): 15531558.

[8]. USDA 2020. Word Agriculture Production. Foreign Agricultural Service United States Department of Agriculture. Circular Series, WAP 6-20, June 2020.

Brief bibliography of the author

\begin{tabular}{|l|l|}
\hline Name & Said Asif Sarbaz \\
\hline F/Name & Said Hanif \\
\hline Date of Birth & $12 / 02 / 1988$ \\
\hline Place of Birth & Kunar, Afghanistan \\
\hline Occupation & $\begin{array}{l}\text { Agriculture Research Farm } \\
\text { Manager, Ministry of } \\
\text { Agriculture, Irrigation and } \\
\text { Livestock of Afghanistan }\end{array}$ \\
\hline M.Sc & $\begin{array}{l}\text { Agronomy, CCS HAU Hisar, } \\
\text { India 17/08/2021 }\end{array}$ \\
\hline B.Sc & $\begin{array}{l}\text { Agronomy, Agriculture Faculty } \\
\text { of Nangarhar university, } \\
\text { Afghanistan 12/06/2012 }\end{array}$ \\
\hline
\end{tabular}




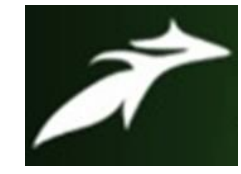

Said Asif Sarbaz et al, International Journal of Advances in Agricultural Science \& Technology, Vol.8 Issue.12, December-2021, pg. 1-10

ISSN: 2348-1358

Impact Factor: 6.057

NAAS Rating: 3.77

\section{List of publication}

1. Said Asif Sarbaz, Satish Kumar, Suresh Kumar, Kautilya Chaudhary, Jogander Kumar, Vinod Kumar Malik. "Effect of integrated nitrogen management on yield and economic of wheat variety WH 1184" published in International Journal of Science and Research (IJSR) Nov-11-2021. 